\title{
Teething troubles for biotechnology centre
}

So near and yet so far? The big question for the Agricultural Biotechnology Centre, the only major research institute to have been built since the Biological Centre was completed at Szeged almost 20 years ago, is whether the new government will have the will to fill it with active researchers and sustain it during its difficult early years. Otherwise what was intended as a magnificent new show piece will instead end up as a white elephant.

The design of the new institute is superb - even in part luxurious, to the embarrassment of the researchers who are trying to explain the terrible financial difficulties of Hungary to visiting

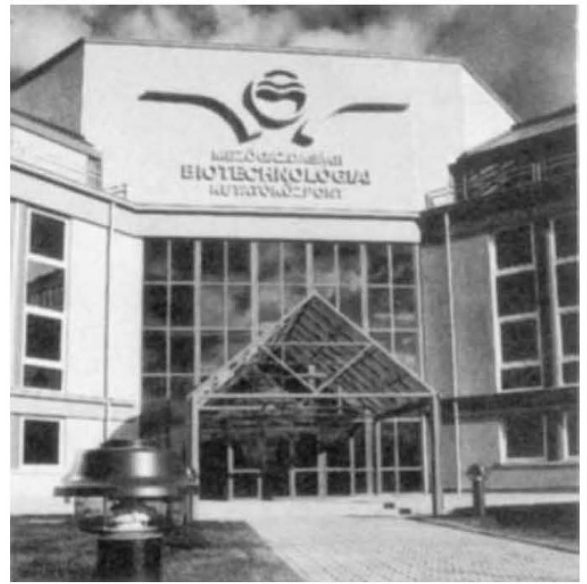
foreigners. A neat trick has been to cap the institute with a floor of greenhouses. By putting the greenhouses on top rather than in a separate building, their construction costs are cut by 40 per cent alongside a similar cut in heating costs. Blinds on top of the glass roof automatically unroll when the sunlight is too strong and roll up again in high winds or snow.

Elsewhere the $\$ 30$ million spent on the institute, including a \$6 million World Bank loan, is much in evidence in new equipment, and in facilities including the latest ultracentrifuges, a Microvax computer, and a pollen-proof greenhouse area for the strict isolation of genetically engineered plants.

The institute belongs to the Ministry of Agriculture, which has its own network of research institutes and is next door to the University of Agriculture at Godollo, a fortyminute drive northeast from Budapest, through some of Hungary's few hills. Many of the institute's staff teach at Godollo, which will also provide a useful source of young researchers.

All the directors are young returnees from top laboratories in Europe and the United States and there is no shortage of good projects to be done. The centre's general director, Ervin Balazs, already has a persuasive list of ideas that will, in the long run, enormously benefit Hungarian agriculture. The trouble is keeping up the level of support needed for 4 or 5 years: "with that support we can publish good results in good journals, attract Western interest". At that stage the institute can hope to win both research contracts and more importantly, long-term support from industry. Until then, the institute must rely on the "shaky hand of government support" as Balazs puts it. The ministries of finance and agriculture are already keen that foreign investors be found. But Balazs says it is unreasonable to expect support from the West until good papers are published. "It is all right to have the facility and equipment", Balazs says, "but they have to know if the driver can drive."

A.A.

The chief worry now is the brain drain that is accompanying Hungary's liberalization. Hungary's citizens are completely free to travel where they like for as long as they like. Pal Venetianer, director of the Institute of Biochemistry, explains that 25 per cent of his institute's staff are currently working in foreign laboratories.

When the institute was set up, a $\$ 12$ million grant from the United Nations Development Project ensured it could be equipped at the European level. In those days, "working here and at NIH did not feel like two different worlds", says Venetianer. But since then the level of funding has slumped, not through any change in policy but because of the deterioration of Hungary's economic situation. The result is a rush to work abroad.

A trip abroad is often essential for more than just scientific advancement. The salaries of scientists in Hungary are so low that without earning some hard currency there is rather little chance of owning a small car, or even buying some decent furniture. At 30 years of age, few basic researchers will earn more than 8,000 forints (\$123) a month, 20 per cent less than an ordinary industrial worker. As rents are often around 2,000 forints for those lucky enough to find a place to live (and much higher in the small private sector), virtually all scientists have some kind of second job - often teaching - or have to earn money through contract research. The second job has become less profitable since Hungary took its first step towards capitalism by introducing an income tax.

When these difficulties are coupled with the many inefficiencies of daily life - the time taken to complete a shopping trip or to locate a needed item is much longer than in the West - then it is no surprise that many Hungarian researchers say that they can be ten times as productive in a good Western laboratory.

Venetianer is, however, determined to hold the line at 25 per cent abroad. "We are trying to adopt a new policy," he says. "All the scientists want to stay away for 5 to 10 years, keeping their positions here open. But we cannot tolerate people going for 3 or 4 years, then just coming back for 6 months and going again. We are trying to be a little bit cruel and force decisions, it's not very popular!" The problem is compounded by the demand for Hungarian scientists abroad. They are already very experienced by the time they get a chance for a trip to the west. "Our senior scientists are very cheap post-docs!", says Venetianer.

\section{How to survive?}

Putting aside internal reforms, the real question for Hungarian science is how it can keep going through what are sure to be several very bad years economically. Help from the West would be much appreciated, particularly help that would allow some of the excellent scientific development. But no one expects help to arrive for nothing. One big risk is that Hungary's scientists may come to be seen as a useful resource for Western industrial development projects - given the salary levels in Hungary, it would be cheap to create some of the new products of genetic engineering, for example. An unpleasant side to this possibility is that there are many experiments which could be performed in Hungary but not in the West the release of genetically engineered organisms, for example, is not strictly regulated.

Becoming a development laboratory for foreign companies would be far from ideal, but as Miklos Benczur of the National Institute of Haemotology puts it, "It would be better than having nothing. It would be very bad for basic science, but if such collaborations can get money for science, then we would have to accept them for two to three years to survive".

If Hungarian scientists have a dream, it is that they should become a normal part of Europe as quickly as possible - participating fully in CERN, EMBO and other European organizations and having access on equal terms to European research funds. But again economics stands in the way, as Hungary needs a convertible currency before this can become possible. Lang optimistically says that this could be possible within 3 years. Alun Anderson

\section{THANKS}

Special thanks go to Bela Lomniczi of the Veterinary Medical Research Institute and Anna Sponaas of the National Institute of Haematology for help and hospitality in Budapest, to Pal Venetianer of the Institute of Biochemistry for hospitality in Szeged and to Lajos Nyiri, Science Attache at the Hungarian Embassy in Washington for his assistance. 